Historic, Archive Document

Do not assume content reflects current scientific knowledge, policies, or practices. 



\section{FALL, 1926}

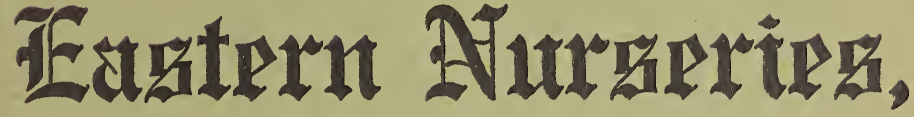

\section{Jncarparated}

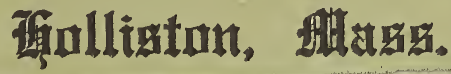

\section{Discount of $15 \%$}

from prices in this list to Landscape Architects and Park and Cemetery Superintendents.

\section{PRICE LIST}

Address all communications to EASTERN NURSERIES, INC., HOLLISTON, MASS.

Telephone, Natick 0345

Telegraph Address, Natick, Mass. 


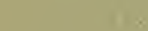

I
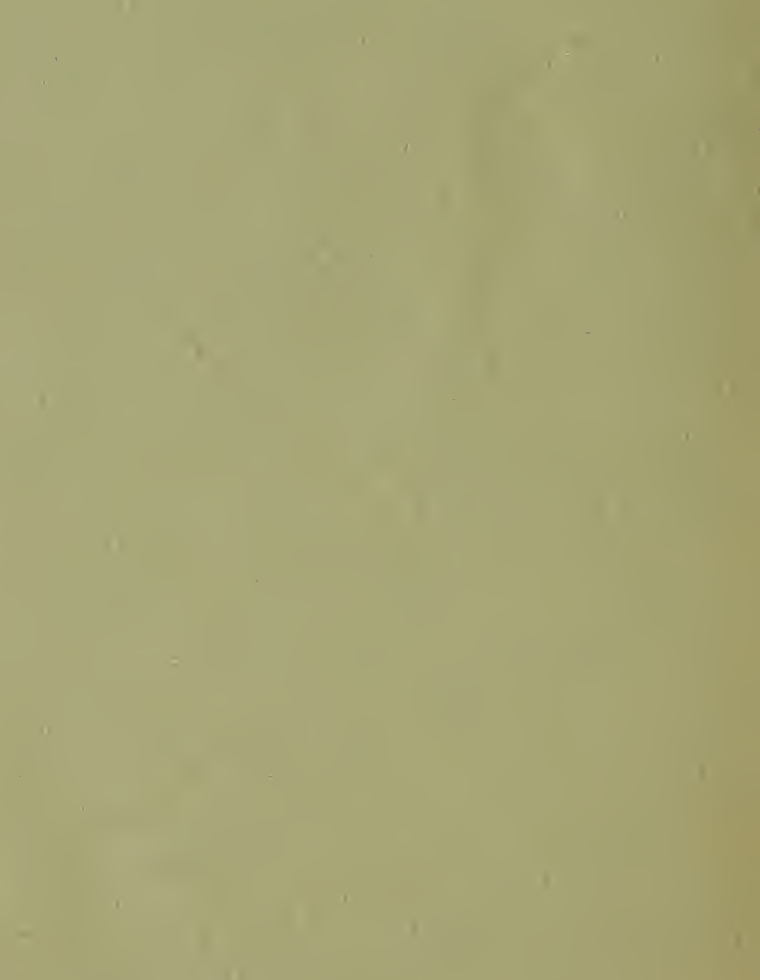

1

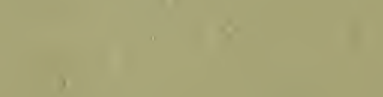

$\sqrt{2}$ 


\section{F A L L, 1926 Eastern Nurseries, Inc.}

Office and Nurseries, HOLLISTON, MASS.

SHIPPING SEASON opens about March 20 to April I in the Spring, and continues until May 20 to June $\mathrm{x}$, and opens about October $\mathrm{I}$ in the Fall, and continues until the ground freezes. Shipping for summer planting of Evergreens opens about August i5th. Pot-grown plants can be shipped and planted at all times.

ORDERS.-Write plainly and give explicit directions as to address and mode of shipment; otherwise we will forward according to our best judgment. All goods travel at purchaser's risk. We assume no responsibility for the goods after delivery to the forwarding companies.

When losses occur by delays in delivery, claims should be made at once on the forwarding companies.

CLAIMS, to receive consideration, must be made within ten (10) days of receipt of goods.

While we exercise the greatest care to have all Trees, Shrubs and Plants genuine and reliable, and hold ourselves prepared to replace, on proper proof, all that prove untrue, we do not give any warranty, expressed or implied; and in case of an error on our part, it is mutually agreed between the purchaser and ourselves that we shall not at any time be held responsible for a greater amount than the original price of the goods.

PACKING.-We take great care in packing, using damp moss to protect roots. Boxes and bales are charged for at cost.

RATES.-The prices in this list supersede all previous rates; and apply to quantities specified, but two hundred and fifty (250) will be furnished at the thousand rate, forty (40) at the one hundred rate, and five (5) at the ten rate, except in the case of perennials when 25 of one kind will be given at the 100 rate. Specimens personally selected by the purchaser or his representative (or specially selected by us at the request of the purchaser) will be priced according to individual values.

This Price List cancels all previous lists and prices are subject to change without notice.

TERMS, CASH WITH ORDERS, except to such persons as satisfy us as to their responsibility. Bills are due when presented and interest will be charged at the rate of six per cent. on bills remaining unpaid December I in Fall and June $I$ in Spring.

A Certificate of Inspection will accompany each shipment. Address all communications to office.

EASTERN NURSERIES, INC., HOLLISTON, MASS. 


\section{PRICE LIST \\ OF \\ Eastern Nurseries, Inc.,}

William F. Dawson, President

Henry S. Dawson, Vice-President

L. B. Dawson, Sec.-Treas.

Office and Nurseries at HOLLISTON, MASS.

Located twenty-six miles southwest of Boston.

\section{FALL, 1926}

Our Evergreens are in especially fine condition this year. Most of them have been transplanted recently and all of them are in excellent condition for Spring planting. We wish to call special attention to our small Evergreens suitable for hedges, group planting and window-boxes, and to our large specimens for immediate effects. Many of these specimens are of unusual beauty and can be moved on platforms, at special prices, which we will gladly quote upon request.

Note.-Look on pages 12 to 19 at our list of Pot-grown Scotch Heather and other ground covers.

A cordial invitation is hereby extended to visit our nursery at any time for the purpose of plant study, or for inspection of saleable stock.

EASTERN NURSERIES, INC.

This Catalogue has been corrected in accordance with the new Book of Standardized Plant Names by the American Joint Committee on Hortlcultural Nomenclature

\section{EVERGREEN TREES AND SHRUBS}

The prices of Evergreens include the burlapping of balls up to 5 feet.

NoTE: On all specimen Evergreens over $12 \mathrm{ft}$. price will include canvas and platform when dug.

Ables concolor W'HITE FIR

Each $10 \quad 100$ All beautiful specimens

14 to $18 \mathrm{ft}$. . . $\$ 50.00$ to $\$ 75.00$ \$ $\$$

homolepis (brachyphylla) Niko FIR

i6 to $20 \mathrm{ft}$. spec. . 5 50.00 to 75.00

nordmanniana NORDMANN'S FIR

$18 \mathrm{ft}$. spec. ... I 100.00

veitchil VEITCH FIR

18 to $24 \mathrm{ft}$. spec. $\$ 60.00$ to 100.00

Andromeda floribunda See Pieris

IPlant Bearberry and Scotch Heather near the sea 
Azalea ledifolia (indica alba) Snow Azalea

Eaon $10 \quad 100$

8 to 10 in. bushy 4 in. pots \$1.50,\$12.50 \$115.00 See also pot-grown plants

Hazel Dawson red NEw Dawson HyBRID

8 to ro in. bushy 4 in. pots . 4.00

Chamaecyparis obtusa Obtuse-Leaved Japanese Cypress

$$
\begin{aligned}
& 3 \text { to } 3^{\frac{1}{2}} \mathrm{ft} \text {...... } 5.00 \\
& \text { pisifera aurea } \\
& \text { Goliden. Sawara Retinospora } \\
& 5 \text { to } 6 \mathrm{ft} \text {...... } 9.00 \\
& \text { fllifera THREAD-RETINOSPORA } \\
& 3 \text { to } 4 \mathrm{ft} . \ldots . .7 .00 \\
& 5 \text { to } 6 \mathrm{ft} . \ldots \ldots \text {. . . I } 2.00 \text { I } 10.00 \\
& \text { plumosa Plume Retinospora }
\end{aligned}
$$

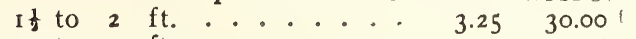

$$
\begin{aligned}
& 2 \text { to } 3 \mathrm{ft} . \ldots . .240 \\
& 12 \text { to } 14 \mathrm{ft} . \times 5-6 \mathrm{ft} \text {. } 25.00 \text { to } 40.00 \\
& \text { aurea }
\end{aligned}
$$

Euonymus radicans acutus SHARPLEAF WINTERCREEPER

4 yr. str. f. g. • • $\quad .75$ carrieri GLOSSY WINTERCREEPER

2 yr. strong . $\therefore \quad 6000$

3 yr. "
large specimens io to 12.00

reticulatus WHITE-VEIN WINTERCREEPER $3 \mathrm{yr} . . . \quad 50$

vegetus BIGLEAF WINTERCREEPER

Lex glabra INKBERRY

$$
3 \text { yr. strong . . . } \quad .75 \quad 6.00
$$

12 to 15 in. . . . . . 2.00

Juniperus chinensis pfitzeriana PFITZER's JUNIPER

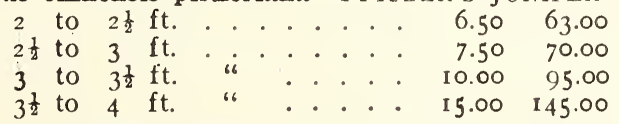

chinensis sargentl SARGENT TRAILING JUNIPER

8 to 12 in. . . . . . 3.50

I $t o r$ I $\mathrm{ft}$. . . . . . . . . 4.5042 .00

It to $2 \mathrm{ft}$....... 6.00

$2 \frac{1}{2}$ to $3 \mathrm{ft}$. spread . . . 12.50

2 to $3 \frac{1}{2} \mathrm{ft}$. spread . . . . 16.00

chinensis (virginalis) globosa

Globe Chinese Juniper

I5 to 18 in. spread .... 6.50

I8 to 24 in. ". . . 8.00

Juniperus communis COMMON JUNIPER

3 , to $4 \mathrm{ft}$. . . . 33.50

Note. The upright Juniper is one of the very hardiest evergreens, and one of the most satisfactory for the New England climate. It keeps its color all winter, and fruits when still quite small. 
Juniperus depressa aurea Golden JunIPER

88 to 24 in. spread . . \$2.50

24 to 30 in. " ... 3.00

horizontalls TRAILING JUNIPER

15 to 18 in. spread... $3.00 \quad 2 \% .30$

sabina SAVIN JUNIPER

It to $2 \mathrm{ft}$.

tamariscifolia TAMAKI SAVIN

8 to 12 in..... 3.00

I to It ft. spread .... 4.00

It to $2 \mathrm{ft}$ " .... 5.00

2 to $2 \frac{1}{2} \mathrm{ft}$. spread ... 7.50

virginiana RED CEDAR Nursery grown

9 to $10 \mathrm{ft}$...... 25.00

10 to $\mathrm{r}_{2} \mathrm{ft.} \ldots \ldots . .35 .00$

13 to $30 \mathrm{ft}$.... 35 to 125.00

Collected. Io to $30 \mathrm{ft}$. Prices on application.

Note. Among the above are many very handsome specimens, particularly among the larger plants, which were moved into the Nursery a few years ago and which will be moved on platforms.

\section{glauca Silver REDCEDAR}
$2 \frac{1}{2}$ to 3 ft. . . . . 7.00
10 to $18 \mathrm{ft} . \ldots \ldots . . .35 .00$
18 to $14 \mathrm{ft} . \ldots . . .50 .00$
schottl SCHOTT REDCEDAR

21 to $3 \mathrm{ft}$ XX spec. . 7.50

tripartita Fountain REDCEDAR

3 to 4 ft. $\times 5-6$ spec. . . 35.00

Kalmia latifolia Mountain LAUREL

15 to 18 in. ...... $2.50 \quad 22.50$

I $\frac{1}{8}$ to $2 \mathrm{ft}$........... 2.7536 .00

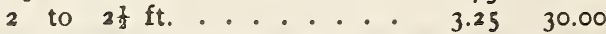

Leucothoe catesbael DROOPING LEUCOTHOE

15 to 18 in. clps...... $2.00 \quad 18.00$

18 to 24 in. clps. . . . $3.00 \quad 36.00$

2 to $2 \frac{1}{\mathrm{~g}} \mathrm{ft}$....... $4.00 \quad 36.00$

Picea albertiana Alberta Spruce

4 to 6 in........... $1.50 \quad \$ 4.00$

A charming symmetrical evergreen, which grows 80 slowly that it will stay in scale for many years.

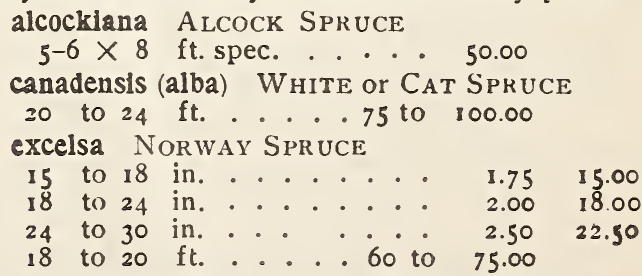

excelsa compacta Globe Norivay Spruce

3 to 4 ft. $\times 3-3 \frac{1}{2} \mathrm{ft}$. tr. 192040.00

5 to $6 \mathrm{ft}$. XXX spec. 40 to 60.00 
EVERGREENS.

Each

100

Picea excelsa parviformis Dwarf Pyramid Spruce

5 to $5^{\frac{1}{2}} \mathrm{ft}$. $\times 5 \frac{1}{2}-6 \mathrm{ft}$. spread

spec. tr. $1920 \cdots+\$ 50.00 \$$

remonti REMONT DWARF SPRUCE

2 to $2 \frac{1}{2} \mathrm{ft}$. . . . . 15.00

5 to $7 \mathrm{ft} \times 6-7 \mathrm{ft}$. . 100 to 150.00

Note. Some of our Dwarf Spruce are wonderful specimens, and all of them have been moved recently. For formal notes or for the foreground of Evergreen plantings these plants are admirably adapted

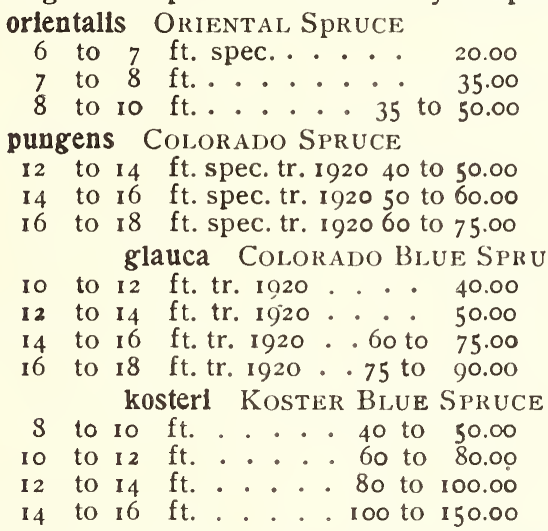

All our specimens of Colorado Spruce, both the Blue forms and the Green forms, were transplanted three years ago and are now in an ideal condition for planting in permanent places.

Pleris (Andromeda) floribunda Mountain Andromeda

15 to 18 in. spread ... 5.00

Pinus cembra Swiss Stone Pine

Io to $14 \mathrm{ft}$. spec. ... 75.00

The Swiss Stone Pine is one of the most beautiful of all pines for formal work. The tree is very slow growing, consequently is important for use as accents where one wishes an accent which will stay in scale many years. Our plants are all beautiful specimens.

excelsa Himalayan Jine

$1 \frac{1}{2}$ to $2 \mathrm{ft}$. $\times 2 \frac{1}{2} \mathrm{ft}$. 7.50 to 10.00

montana mughus Mugho or DWarf Mountain Pine

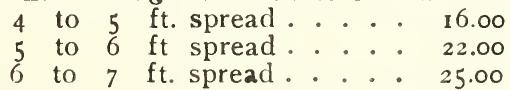

Our entire block of Mugho Pines was transplanted three years ago, and they are now in wonderful condition for planting. Among them are many very fine specimens of the various types of this useful plant. 


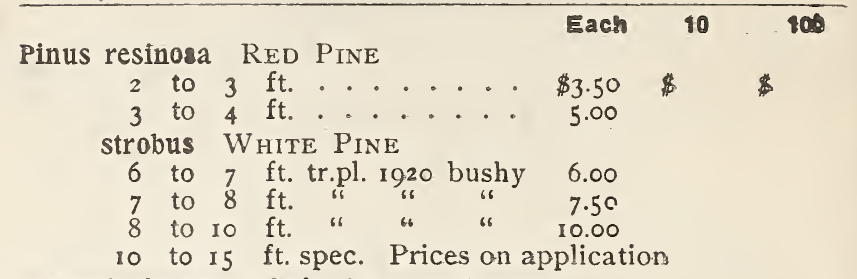

Pseudolarix kaempferi GoLdEN LARCH

8 to $9 \mathrm{ft}$.spec. B \& B .. 25.00 Pseudotsuga douglasi Dovglas FIR

8 to $10 \mathrm{ft}$. . . . 16.00

10 to $12 \mathrm{ft} . \ldots \ldots . . .18 .00$

12 to $14 \mathrm{ft} . . . . .20 .00$

Rhododendron hybrids, all well budded plants Abraham Lincoln Fine red

$3 \mathrm{ft}$....... 10.00

Album eiegans Large white

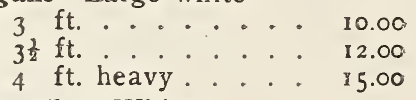

Catawbiense alba White

2 to $2 \frac{1}{2} \mathrm{ft} . \ldots . .780$

Charles Dickens Scarlet early

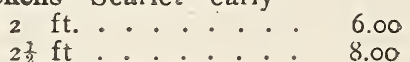

Delicatissimum Blush white

$3 \mathrm{ft}$..... 10.00

E. S. Rand Rich crimson

$2 \mathrm{ft}$..... 6.50

Everestianum Rosy lilac

2 ft. ..... 6.50

Flushing

$2 \frac{1}{2} \mathrm{ft} . \ldots 8.50$

General Grant Red

$2 \frac{1}{2} \mathrm{ft} . \ldots . . .8 .50$

Grandiflorum Clear rose

$$
2 \frac{1}{2} \mathrm{ft} . \ldots . . .8 .50
$$

$2 \frac{1}{2} \mathrm{ft}$. 8.00

3 ft. . . . 10.00

$3 \frac{1}{2} \mathrm{ft} . \ldots . . .15 .00$

Kettledrum Rich crimson

$$
\begin{aligned}
& 2 \mathrm{ft} \text {..... } 6.50 \\
& 2 \mathrm{t} \mathrm{ft} . \ldots . . .8 .50
\end{aligned}
$$

Lee's Dark purple

$$
\begin{aligned}
& 2 \mathrm{ft} . \ldots . .660 \\
& 2 \frac{1}{2} \mathrm{ft} . \ldots . . .8 .50
\end{aligned}
$$

Memoir Blush white

$$
2 \frac{1}{2} \mathrm{ft} . \text {. . . . . } 8.50
$$

Mrs. Charles S. Sargent Pink

$$
3 \mathrm{ft} . \text {..... } 10.00
$$

President Lincoln Rosy crimson

$$
2 \mathrm{ft} . \ldots .6 .50
$$

Plant Bearberry and Scotch Heather near the sea 
EVERGREENS.

Rhododendron hybrids

Each $10 \quad 100$

Purpureum elegans Best purple

If $\mathrm{ft} . \cdots \ldots+\$ 5.00 \$$

Roseum elegans Deep rosy pink
$2 \mathrm{ft}$. . . . 8.50
$2 \frac{1}{2} \mathrm{ft} . \ldots . . .10 .00$
$3 \mathrm{ft.}$...... 15.00

laetevirens (wilsonianum) WILSON RHODODENDRON

15 in. $\times 15-18$ in. . 5.00

18 in. $X I^{\frac{1}{8}} 2 \mathrm{ft}$. . . 6.00

Rhododendron maximum ROSE BAY RHODODENDRONS

nursery grown

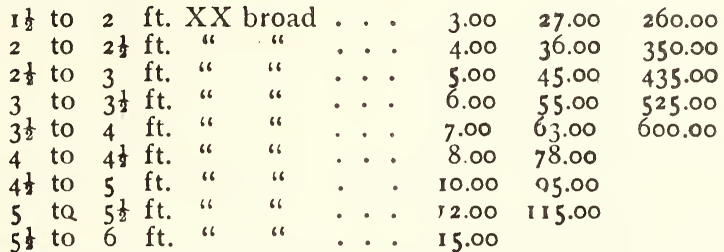

COLLECTED CLUMPS F.O.B. our shipping point in

Pennsylvania in carload lots.

2 to $5 \mathrm{ft}$. mixed clumps at $\$ 500$ per carload

5 to $8 \mathrm{ft}$. XXX broad specimen clumps

Prices on application

We make a specialty of collecting Rhododendron Maximum in carload lots. The plants vary in size from $\mathrm{I}$ to $5 \mathrm{ft}$. From 65 to 350 plants can be put into a car, depending upon the size of the plants. We ship only first class plants.

Taxus canadensis CANADA YEW

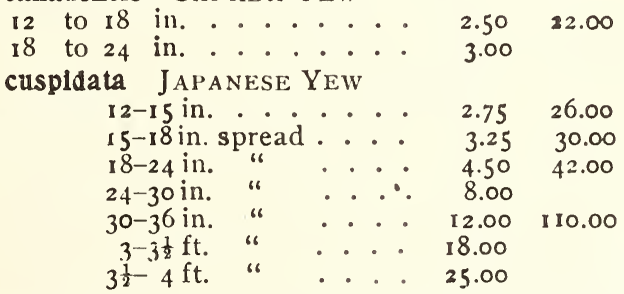

Our Taxus cuspidata are all heavy plants, recently transplanted. We believe there is no finer stock of this indispensable Evergreen in this country.

densa Compact DWarf Japanese Yew 8-12 in. spread ... 4.00 $12-15$ in. " ... 5.00 $15-18$ in. " ... 8.00 
Each $10 \quad 100$

Taxus cuspidata nana (brevifolia) DWARF JAPANESE YEW

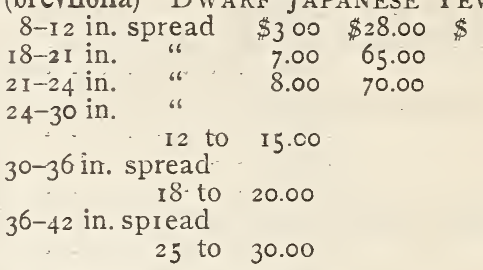

Thuja occidentalis AMERICAN ARBOR Vitae

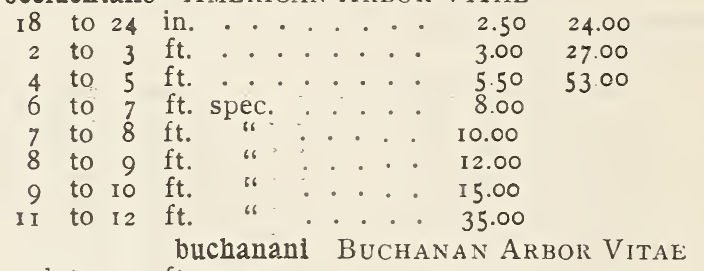

$2 \frac{1}{2}$ to $3 \mathrm{ft}$. spec. . . 4.00

I0 to I2 ft. " . . 35 to 40.00

douglasi pyramidalis

Douglas Pyramidal Arbor Vitae

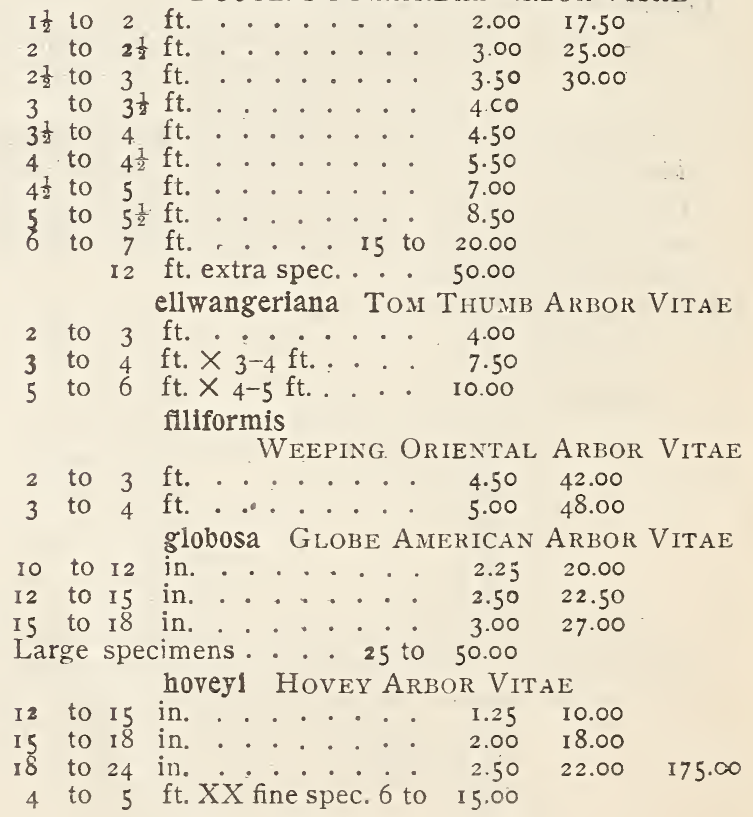

Plant Bearherry and Scotch Heather near the sea 
Each $10 \quad 100$

Thuja occidentalis Little Gem LitTle Gem Arbor Vitae

8 to 12 in. spread ..... $\$ 2.50 \$ 20.00 \$$

12 to 15 in. ..... 3.00

15 to 18 in. ...... 4.00

18 to 24 in. ..... 7.50

lutea George Peabody Arbor Vitae

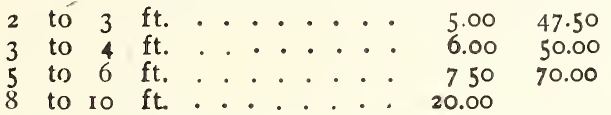

pyramidalls Pyramidal ArBor VitaE

3 to $3 \frac{1}{2} \mathrm{ft} . \ldots \ldots . . .500$

6 to $7 \mathrm{ft}$........ 10.00

7 to $8 \mathrm{ft} . \ldots \ldots . . .15 .00$

8 to $9 \mathrm{ft.} . . .20 .00$

reldi REID ARBOR VITAE

12 to 15 in. . . . 2 $2.75 \quad 26.00$

18 to 24 in. . . . . . 3.2530 .00

2 to 3 ft. ........ $3.50 \quad 33.00$

3 to $4 \mathrm{ft}$. heavy .... 7.50

4 to 5 ft. XXX spec. . 20.00

5 to $5 \frac{1}{2} \mathrm{ft}$. XXX spec. - 25.00

rosenthall ROSENTHAL ARBOR VITAE

12 to 15 in. . . . 3.0028 .00

15 to 18 in. ..... 3.2530 .00

24 to 30 in. ..... 4.50

30 to 36 in. ..... 6.00

36 to 42 in...... 7.50

Tom Thumb

18 to 24 in. . .... 5.00

vervaeneana Vervaene Arbor Vitae

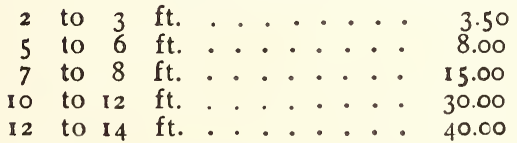

warreana WARE ARBor Vitae

15 to 18 in. ..... 3.0027 .00

18 to 24 in. ..... 3.5033 .00

4 to $5 \mathrm{ft}$. spec. . . 8.00

5 to $6 \mathrm{ft}$. XX spec.16.50 to 18.00

6 to $7 \mathrm{ft}$ XXX spec. . 25.00

7 to $8 \mathrm{ft}$. " " 30 to 35.00

Waxen Golden ARBor VitaE

2 to $2 \frac{1}{2} \mathrm{ft}$. . . . . . . $2.50 \quad 22.00$

6 to $7 \mathrm{ft}$. $\times 7-8 \mathrm{ft}$. XXX spec.

woodwardi

50 to 60.00

Woodward Globe Arbor Vitae

12 to 15 in. ..... 2.75

Most of our Arbor Vitaes have been transplanted within the last two years, and are in prime condition for hedges or specimens. 
Truga canadensis AMERICAN HEMLOCK

$$
2 \frac{1}{3} \text { to } 3 \mathrm{ft} . \ldots \ldots . . \$ 4.50 \$ \$
$$

3 to $3 \frac{1}{2} \mathrm{ft.} \ldots \ldots . . . .60$

$3^{\frac{1}{2}}$ to $4 \mathrm{ft}$. . . . 7.50

8 to $9 \mathrm{ft.}$. . . . . 2. $25.0 \mathrm{c}$

9 to ro ft. ...... 30.00

carolimiana Carolina HemLOCK

2 to $2 \mathrm{t} \mathrm{ft} . \ldots \ldots . .3 .50$

3 to $3 \frac{\mathrm{ft}}{\mathrm{ft} .}$...... 6.00

$3 \frac{1}{2}$ to $4 \mathrm{ft}$. . . . . 7.50

Our Hemlocks, too, have been transplanted recently and all are beautiful, broad, specimens, which came through last winter unharmed. 


\section{LIST OF POT-GROWN PLANTS}

\section{Which can be shipped and planted at all times}

Aethlonema grandlflorum superba PERSIAN STONECRESS

2 in. pots . . . . . . \$ $\$ .60 \$ 5.00 \$$

Althionema grandiflorum var. glauca

2 in. pots........ . . . . . $50 \quad 5.00$

Ampelopsis tricuspidata (veitchi) JAPANESE CREEPER

3 in. pots 2 yr. . . . . . . $75 \quad 7.0060 .00$

Anisostichus capreolata CRussvine

$2 \frac{1}{2}$ in. pots . . . . . . . $75 \quad 7.00$

Arctostaphylos uva-ursi BEAR-BERRY

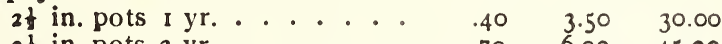

2 in. pots 2 yr. . . . . . $\quad .70 \quad 6.00 \quad 45.00$

$2 \frac{1}{8}$ in. pots 3 yr. . . . . . . . $75 \quad 7.00 \quad 50.00$

4 in. pots heavy . . . . . $1.25 \quad 10.00 \quad 90.00$

Azalea ledilolia (indica alba) SNOW AzALEA

4 in. pots ......... $1.50 \quad 12.50$

Hazel Dawson DAwson HyRRID new

4 in. pots . . . . . . 4.00

indica pink

4 in. pots . . . . . . 2.00

obtusa kiusiana Kurume Azalea

Originated in the city of Kurume, on the Island of Kyashu, Japan, nearly roo years ago, these beautiful plants have been practically unknown in Europe and America until brought to the attention of the public a few years ago by Mr. E. H. Wilson, of the Arnold Arboretum. The plants of this group are of dwarf, compact habit, with small, deep green, glossy, evergreen foliage, and small flowers, borne in great profusion, and covering the plants for many weeks with their fairy clouds of exquisite color. Many of the varieties have flowers known as "hose-inhose," that is, having a petaloid calyx and giving the effect of one corolla set within another.

Kurume Azaleas are hardy on Long Island, New York, and thence south. In the north these plants are of untold value for forcing for winter bloom in conservatory or greenhouse. From a collection of over 200 sorts Japanese experts have selected what they consider the best six vari. eties. We are now offering for sale plants of these six varieties, raised from cuttings. With one exception the varieties offered have hose-in-hose flowers.

The six varieties referred to are:

TAKASAGO, pure pink, hose-in-hose

AzUMA-KAGAMI, deep pink, hose-in-hose

KIRIN, deep rose, shading to silvery rose, hose in-hose

KUMO-NO-NYE, pure salmon, single

KURAI-NO-HIMO, pure carmine, hose-in-hose

KURENO-YUKI, pure white, hose-in-hose

For prices see pages $11-12$ 


\section{Each $10 \quad 100$}

$\$ 18.00$ per set of one each of the above plants 4 years old, in 5-inch pots, packed for shipment.

Bruckenthalla spicullfolia SPIKE HEATH. Flowers pink, blooming from June to August. Grows 6 in. high 4 in. pots...... \$1.50 \$13.50 \$

Buddlela davldi Orange-Eye Butterfly Bush

$$
4 \text { in. pots ............ .60 } 5.50
$$

Callicarpa dichotoma Chinese Beautyberry

$$
3 \text { in. pots . ...... . . . } 75 \quad 7.00
$$

Calluna vulgaris Sсотсн НЕAтнек, and named varieties

Scotch Heather, the "Bonnie Purple Heather" of song and verse, is a lovely, low-growing evergreen shrub, 6 in. to $3 \mathrm{ft}$. in height, of the Heath. Family, covered in midsummer with small, bell-shaped purple flowers, borne on slender spikes. These flowers stay in good condition for some weeks, and if cut while fresh will hold their color and charm all winter. Honey bees, too, are attracted to Scotch Heather and make from it a honey that is considered very choice. This plant is widely known as invaluable for planting in full sun in sandy soil: it is also most attractive as an edging to beds of Rhododendrons, Laurel, etc., and in Rock Gardens. This little plant gives most satisfaction when planted from pots. Besides the common purple Heather there are many varieties which give variation in the height of plant, color of flowers. and season of bloom. Below we offer a list of varieties, all of which are pot grown, sturdy plants. $2 \frac{1}{\mathrm{y}}$ and 3 in. pots

flora plena A double-flowered form of our plain Scotch Bonnie Purple Heather. $2 \frac{1}{2}$ and 3 in. pots

var. alba White SCOTCH Heather, early blooming, with light green foliage, white flowers, grows 12 to 15 inches. $2 \frac{1}{3}$ and 3 in. pots

var. alba elata TAll White Heather. Late blooming, very tall, straight growth. Foliage soft dark green, flowers white, grows 18 to $24 \mathrm{in} .2 \frac{1}{2}$ and $3 \mathrm{in}$. pots

var. alba erecta TALL White HeAther. Late blooming, foliage dark green, flowers white, grows 18 in. $2 \frac{1}{8}$ and 3 in. pots

var. alba hammondi Hammond White Heather. Midseason, tall upright growth, foliage rich deep green, flowers white, grows 18 to 24 in. high. $2 \frac{1}{2}$ and 3 in. pots

var. alba minor Dwarf White Heather. Mid-season tall bushy growth, 15-20 in. high, foliage very fine light green; flowers white. $2 \frac{1}{2}$ and 3 in. pots

var. alba pllosa Late blooming, tall growth $18-20$ in. high, foliage of soft grayish green, flowers white. $2 \frac{1}{2}$ and 3 in. pots

var. alba rigida BRUSH HEATHER. Late, low rigid growth, foliage rich deep green, flowers white. 3 in. pots

var. alba searlil Foliage golden, not very noticeable in winter, nor objectionably tall, grows 18 to 20 inches. $2 \frac{1}{2}$ in. pots

var. alba spicata TAll Whıte Heather. New. Grows 20 to 24 in. high. $2 \frac{1}{3}$ and 3 in. pots 
Calluna vulgaris

var. alporti AlPORT HeAther. Late blooming, tall straight growth to 84 in. foliage deep rich green, turning purple in autumn. Flowers rosy carmine. $2 \frac{1}{2}$ and 3 in. pots

var. argentea Flowers pink, foliage whitish, yellow green. Grows 15 to 18 in. high. $2 \frac{1}{2}$ in. pots

var. aurea Golden foliage and pink flowers, one of the best of those with colored foliage. $2 \frac{1}{2}$ and 3 in. pots

var. compacta Late blooming. Low compact, moss-like growth, 4 to 6 in. high, of bright, rich green. Flowers pale lavender. $2 \frac{1}{8}$ in. pots

var. cuprea Mid-season. Straight medium growth 12 to I 5 in. high, foliage bright, almost yellowish green, turning to rich glowing red in autumn. Flowers purple. $2 \frac{1}{2}$ and 3 in. pots

var. hirsuta (tomentosa). Woolly Heather. Midseason. Low compact growth. 4 to $7 \mathrm{in.} \mathrm{high,} \mathrm{foliage} \mathrm{soft}$ gray, flowers purple. $2 \frac{1}{2}$ and 3 in. pots

var. humilis Low growing, with rich green foliage. Flowers, midseason. white. $2 \frac{1}{1}$ in. pots

var. hypnoides Late blooming. Low-spreading growth, 6 to 12 in. high. Foliage soft deep green, flowers deep pink. $2 \frac{1}{2}$ and 3 in. pots

var. monstrosa Loose growth. Flowers pink. $2 \frac{1}{2}$ in. pots var. rosea Mid-season. Tall, straight-growing, with deliicate pink flowers. $2 \frac{1}{2}$ and 3 in. pots

var. rubra RED HEATHER. Early blooming, with low spreading growth, 6 to 12 in. high. Foliage soft green turning purple in autumn. Flowers rosy carmine. $2 \frac{1}{2}$ and 3 in. pots

var. tenella Slender Heather. Early blooming. Low growth with slender spikes of dainty lavender flowers. $2 \frac{1}{2}$ and 3 in. pots.

var. variegata Very bright, whitish green foliage, pink flowers, grows 15 to 20 in. high. $2 \frac{1}{2}$ in. pots

Prices on Heather and varieties:

$$
\text { Each } 10 \quad 100
$$
$2 \frac{1}{2}$ in. pots.......
3 in. pots........
$\$ .50 \$ 4.50 \quad \$ 36.00$ $\begin{array}{lll}.75 & 6.00 \quad 50.00\end{array}$

Cerastium biebersteimi TAURUS CēRASTIUM
3 in. pots

Clematis montana rubens Pink

4 in. pots....... $2.00 \quad 18.00$

Corema comradi BroOM CROWBERRY

$$
2 \frac{1}{8} \text { in. pots............. } 50 \quad 4.75 \quad 45.00
$$

Coronilla emerus SCORPION-SENNA
3 in. pots........................
$1.00 \quad 8.50$

Note: The Cotoneasters are among the most important groups of hardy plants which have recently been brought before the public. All of them have attractive foliage and conspicuous berries. Of those listed below C. adpressa, horizontalis and its variety perpusilla, and C. microphylla are of low-spreading growth, have small 
Each 40

glossy, evergreen-like foliage and bright red berries which stay on the shrubs well into the winter. The plants of this group of Cotoneaster are particularly adaptable for use in rockery, on the edge of low shrubberies or on slopes. C. Dielsiana, divaricata and salicifolia floccosa are of more shrub-like growth, with long graceful branches, glossy leaves and bright red berries. All of these plants are hardy and do well in any good well-drained garden soil, but require plenty of water during the first year after transplanting, and take hold much more satisfactorily when transplanted from pots than from the field.

Cotoneaster adpressa CREEPING COTONEASTER

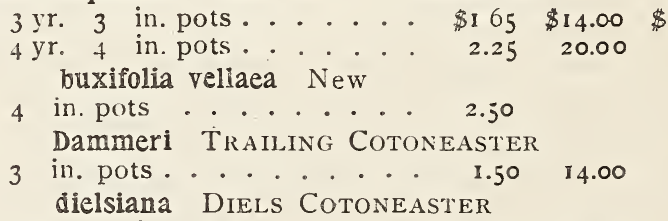
3 yr. 3 in. pots ..... $3.25 \quad 10.00$
3 yr. 4 in. pots..... . $2.00 \quad 15.00$
dielsiana elegans
$\begin{array}{llllll}3 \text { yr. } 3 \text { in. pots . . . } & 1.25 & 10.00\end{array}$
3 yr. 4 in. pots.... 2.00
divaricata SPREAding Cotoneastek

3 yr. 3 in. pots...... $\quad .85 \quad 7.50 \quad 65.00$

3 yr. 4 in. pots..... 1.25

gracilis New

4 in. pots....... 1.50

horizontalis ROCK COTONEASTER

3 yr. 3 in. pots.... 80

3 yr. 4 in. pots..... 1.50

var. apiculata

3 in. pots... ..... $\quad 1.50 \quad 13.50 \quad 125.00$

4 in. pots..... .. $2.25 \quad 20.00$

perpusilla

3 yr. 3 in. pots..... $1.00 \quad 8.00 \quad 65.00$

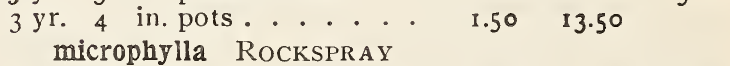

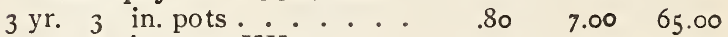

3 yr. 4 in. pots XX str. .. $1.40 \quad 11.50 \quad 100.00$

racemiflora soongarica

4 in. pots....... 2.00

salicifolia floccosa WilLow LEAF Cotoneaster

3 yr. 3 in. pots...... 1.5013 .00

3 yr. 4 in. pots..... $2.00 \quad 18.00$

wilsoni Wilson Cotoneaster

3 yr. 3 in. pots ..... 1.009 .00

Cytisus purgans Provence Broom

$2 \frac{1}{2}$ in. pots . . . . . 1.008 .00

scorparius Scotch Broom

$2 \frac{1}{2}$ in. pots. . . . . . . $\quad 75 \quad 7.00$

Plant Bearberry and Scotch Heather near the sea 


Each $10 \quad 100$

Daphne cneorum GARLAND FLOWER

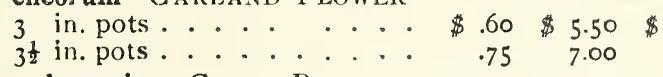

Dianthus plumarius CLOVE PINK

$$
2 \frac{1}{2} \text { in. pots......... . . . . . } \quad .35 \quad 3.00 \quad 25.00
$$

Dorycnium hirsutum GRAY Foliage $2 \frac{1}{4}$ in. pots................ $60 \quad 5.50 \quad 50.00$

Erica carnea SPRING HeAth

$$
\begin{aligned}
& 2 \frac{1}{2} \text { in. pots......... . . . . } 50 \quad 4.75 \quad 45.00 \\
& 3 \text { in. pots........ } .65 \quad 6.005000
\end{aligned}
$$

stricta CORSICAN HEATH

3 in. pots......... . . . . . . $75 \quad 7.00$

tetralix CROSS-LEAF HEATH

$$
2 \frac{1}{8} \text { in. pots......... . . . . . . } 60 \quad 5.00 \quad 45.00
$$

vagans CORNISH HEATH

3 in. pots......... . . . . . $70 \quad 6.50 \quad 50.00$

Euonymus radicans acutus SHARPLEAF W'INTERCREEPER
3 in. pots 3 yr. XX strong . $\quad .75 \quad 6.00$ colorata New

3 in. pots........ . . . . $75 \quad 7.00$ kewensis BABY WINTERCREEPER

3 in. pots............. $60 \quad 5.50 \quad 50.00$

Genista pilosa Silkyleaf Broom

$2 \frac{1}{2}$ in. pots . . . . . . . $1.00 \quad 8.00$

Gypsophila repens CREEPING GYPSOPHILA

2 in. pots......... $\begin{array}{lllll}.30 & 2.50 & 18.00\end{array}$

Hedera helix ENGLish Ivy

4 in. pots......... . . . . . . 6500

Helwingla japonica

3 in. pots . . . . . . 1.008 .00

Hellanthemum SUN Rose, and named varieties

3 in. pots ....... 1.00

alyssoides No. 1623I

appeninum No. 15448

chamaecistus No. 4667-2. Single, orange pink stramineum No. $743-1$

Clear, lemon yellow flower pilosum purpureum No. 15443 polifolium No. 16234 pulverulentum No. 16227 umbellatum No. 15450 variabile No. 16236 vulgarl No. 15451 Single, white variegatum No. 15449

2 in. pots........ . . . . . . $50 \quad 5.00$

Heuchera sanguinea

3 in. pots......... . . . . . . . 40 40

Byperlcum buckleyi Mountain St. Johnswort

$2 \frac{1}{2}$ in. pots........ . . . . . . . $50 \quad 50$

calycinum ROSE OF SHARON

$2 \frac{1}{2}$ in. pots............... $40 \quad 3.00 \quad 25.00$

For prices see pages $11-12$ 


\section{Each 10}

100

Iberis sempervirens HARDY EVERGREEN CANDYTUFT

2 in. pots ....... \$ $\$ 25 \$ 2.00 \$ 16.00$ $2 \frac{1}{2}$ in. pots . . . . . . . $\quad .30 \quad 2.50 \quad 18.00$

var. Little Gem Compact Evergreen Candytuft

2 in. pots........ . . . $35 \quad 3.00 \quad 20.00$ tenoreana TENORE CANDytuft

$2 \frac{1}{2}$ in. pots........... $30 \quad 3.60$

Jasminum primulinum PRIMROSE JASMINE
3 in. pots.
.75
6.00

Lithospermum fruticosum (prostratum) SHRUBBy CROMWELL

21 in. pots........ . . . $75 \quad 7.00$

Lonicera henryi HenRy HONEYSUCKLE New

3 in. pots....... : $75 \quad 6.00$

pileata Privet Honeysuckie

This Honeysuckle, also, is evergreen. The growth of this shrub is somewhat stiff, and spreading, the foliage $\frac{1}{8}$ to I inch long, rather box-like, and bright shining green. While still a small plant L. pileata is covered with small yellow flowers which produce in early autumn beautiful transparent berries of clear light purple. Like L. nitida this shrub does not always survive the severe winters of this climate; but in southern New England and south and west it is one of the most useful and beautiful of the new shrubs. It will serve as a specimen shrub in the garden, a shrub for rockgardens, or as a low, wide-spreading hedge.

$$
4 \text { in. pots...... } 1.00 \quad 7.50
$$

Nepeta mussini

$$
2 \text { in. pots........ } 30 \quad 2.50 \quad 18.00
$$

Pachistima canbyi Canby Pachistima

$$
2_{4}^{1} \text { in. pots } 3 \text { yr. ....... } 70 \quad 5.50
$$

Pachysandra terminalis JAPANESE PACHYSANDRA
2 in. pots .. \$IIO per M
3 in. pots ...\$125 per M

Paparer Gerald Perry Apricot pink

3 in pots . . . . . 1.00

Lord Lambourne New, bright scarlet

3 in. pots . . . . . I.50

Mahoney Queen Carmine purple

3 in. pots ....... 1.00

Mrs. Perry Salmon-rose

3 in. pots........ $\quad .75 \quad 7.00$

Princess Eva Crimson

3 in. pots ....... 1.00

Princess Victoria Louise Soft salmon-rose

3 in. pots . . . . . $1.00 \quad 9.00$

Queen Alexandria

3 in. pots . . . . . $1.00 \quad 9.00$

Royal Scarlet Red with dark center

3 in. pots . . . . . 1.009 .00 
Each 10

100

Phlox subulata alba White Moss
2 in pots ...... \$ $\$ 25 \$ 2.50 \$$ \$I 8.00 var. lllacina Lilac Moss

2 in. pots............. $30 \quad 2.50 \quad 18.00$

subulata var. G. F. Wilson LAVENDER Moss

2 in. pots........... $30 \quad 2.50 \quad 18.00$

vivid PINK Moss

2 in. pots....... . . . $30 \quad 2.50 \quad 20.00$

Potentilla tridentata Wineleaf Cinquefoil

$2 \frac{1}{2}$ in. pots XX strong ... $\quad .35 \quad 3.00 \quad 25.00$

Pyracantha coccinea SCARLET FIRE THORN

ro to 14 in. 4 in. pots ... 2.00

\section{Rosa Alberic Barbier}
4 in. pots
1.2510 .00

American Pillar Climber of strong growth with rich glossy foliage and huge clusters of large, cherry-colored flowers
4 in. pots.
$.75 \quad 7.00$

Arnold Dawson hybrid. Rugosa. It is a stout bush with good foliage and large, bright red, single flowers
3 in. pots ..... 2.50
4 in. pots ...... 3.00
bella SOLITARy Rose

3 in. pots ....... 2.00

Betty Blossom Dawson hybrid, climbing rose, glossy foliage and large delicate pink flowers, early, flowering just before Dr. Van Fleet

3 in pots 4.2 .75
4 in. pots 2.00

Blanc de Coubert Immense fragrant, pure white flowers
4 in. pots
I.25 10.00

Caudata It is a large, strong-growing hardy shrub with stout arching stems, dark green leaves, and flowers two inches in diameter, in wide clusters, each containing from twenty to twenty-five flowers which are pale pink

$$
3 \text { in. pots...... } 8.00
$$

\section{Crimson Rambler}

$$
4 \text { in. pots........... } 75 \quad 6.00
$$

Dawson A Dawson hybrid climber of rambler habit. Flowers semi-double deep pink in large clusters. Early

$$
4 \text { in. pots XX strong ... } \quad .75
$$

Daybreak A Dawson hybrid. Climber with glossy foliage and large clusters of single deep salmon pink flow. ers in July

$$
4 \text { in. pots...... } 1.00 \quad 7.50
$$

Dorothy Perkins Climber with glossy foliage and clus ters of late-blooming, deep-pink, double flowers
4 in. pots
.75
6.00

Dr. Van Fleet Strong growing climber with glossy foliage and large double shell pink flowers in early July
4 in. pots........... I. 5

ecae ECA Rose For June shipment only

3 in. pots...... 2.00 
Excelsa Climbing wichuraiana hybrid bearing clusters of double brilliant red flowers late in season

$$
4 \text { in. pots...... \$1.00\$\$ \$ }
$$

Harrison's Yellow Old-fashioned yellow Rose
3 in. pots ......... $1.35 \quad 10.00$
4 in. pots . . . . . . I.:0

Helenae Helen Rose. Shrub with slender branches and large clusters of pure white fragrant flowers. Considered by the Arnold Arboretum one of the handsomest of all roses brought from China by Mr. Wilson

3 in. pots . . . 4.00

hibernica grovesi Irish Rose. Single flowered pink rose closely related to the Scotch Rose

3 in pots . . . . . 1.25

hugonis Father Hugo's Rose. An upright rose with stems covered in early spring witn single clear yellow flowers before the foliage appears

3 in. pots....... $1.75 \quad 15.00$

4 in. pots...... $2.00 \quad 17.50$

Jacki Low growing or trailing rose from Korea with long-pointed glossy foliage, and large clusters of white flowers with yellow centers. Blooms late
4 in. pots
2.00

Lady Duncan A Dawson hybrid, semi-climber, with rich green rugosa-like foliage, and large clear salmon-pink flowers, blooming in late June. Absolutely free from injurious pests

3 in. pots .......... $1.50 \quad 13.50$

4 in. pots........... I.75 I5.00

Lady Gay Pink climber much like Dorothy Perkins
4 in. pots.
.75
6.00

Minnie Dawson Dawson hybrid. Rambler of the Dawson habit, the flowers small double white borne in large clusters
4 i
in. pots
1.75

Mme. Plantier Pure white, very free bloomer

3 in. pots......... $1.25 \quad 10.00$

4 in. pots......... $1.50 \quad 12.50$

micrantha

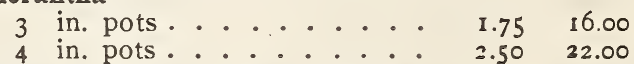

moyesil MOYes Rose. Tall shrub of loose growth, with large pointed foliage and small deep red flowers, followed by long orange-red fruits. Introduced from China by $\mathrm{E}$. H. Wilson

3 in. pots . 4.2 .00

multibracteata An attractive plant with small leaves and small flowers in cluster, clear pale pink, single

3 in. pots ...... 2.00

multiflora catheyensis CATHAY ROSE. The pink multiflora from China

3 in. pots....... $75 \quad 7.00$

Plant Bearberry and Scotch Heather near the sea 
Each 10

Rosa omiensis Mount Omei Rose

4 in. pots ....... \$2.00\$\$ $\$$

Pauline Dawson A Dawson hybrid climber or pillar rose of good foliage and large single deep pink flowers

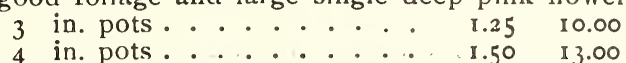

Paul's Scarlet Climber

3 in. pots........... I. $1.25 \quad 10.00$

4 in. pots........ $1.50 \quad 12.50$

Persian Yellow

3 in. pots........ $1.25 \quad 10.00$

4 in. pots........... $1.50 \quad 12.50$

Purity Pure white, climbing

3 in. pots............ $1.25 \quad$ I 2.50

4 in. pots.......... $1.50 \quad 12.50$

rugosa repens alba Climbing or creeping white-flowered rugosa hybrid, with glossy foliage and large star-shaped white flowers
3 in. pots
4 in. pots.
1.25
10.00

Sargent Dawson hybrid, semi-double pink
4 in. pots .
I.50

Seashell Dawson hybrid. Climber which has glossy foliage and large clusters of large semidouble pink flowers, blooming in July
4 in. pots
I.50

Silver Moon Climber with glossy rich foliage and large single cream white flowers, blooming in July

4 in. pots........ I.00 7.50

spinosissima Scotch Briar

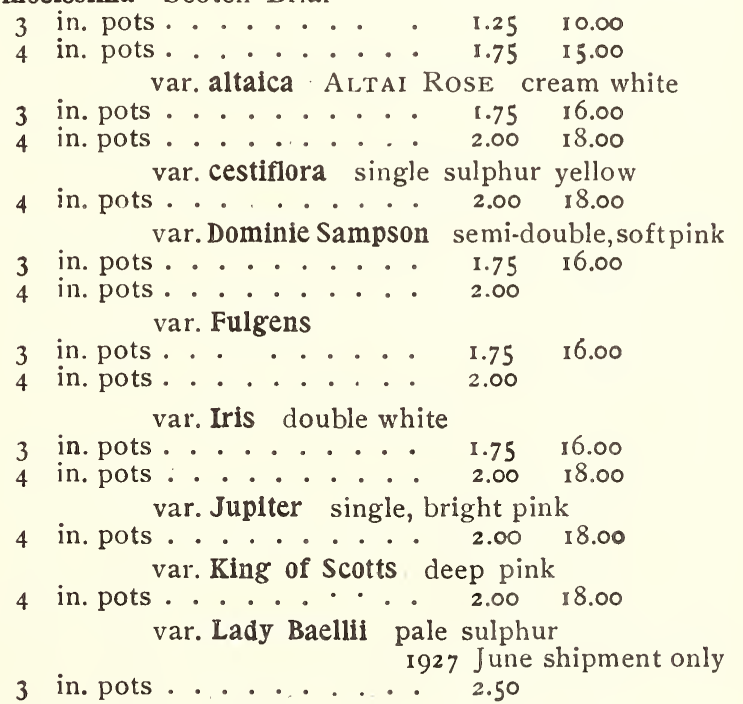

For prices see pages $11-12$ 
Rosa spinosissima var. Plato clear red

$$
\text { Each } 10 \quad 100
$$

3 in. pots ....... $\$ 1.75 \$ \$ 16.00 \$$

4 in. pots ...... 3.00

var. Py thagoras semi-double, light pink flecked with deep pink

3 in. pots ............. 1.7516 .00

Tausendschon Climber. Good foliage, flowers large, shell pink fading to white. Late bloomer. July

4 in. pots.......... $75 \quad 6.00$

William C. Egan A Dawson hybrid, climber, with good foliage and large very double pink flowers. Late June

4 in. pots....... $1.00 \quad 7.50$

xanthina KOREAN Rose, single. A bush rose, new, from northern China, with yellow flowers

4 in. pots . . . . 2.50

KOREAN Rose, double yellow

4 in. pots...... 2.50

We have also a large collection of field grown Roses

Sedum acre Goldmoss

$2 \frac{1}{8}$ in. pots............ $30 \quad 2.50 \quad 18.00$

dasyphyllum LEAFY STONECROP

$2 \frac{1}{2}$ in. pots........ $40 \quad 3060$

hispanicum SPANish Stonecrop gray foliage

$2 \frac{1}{2}$ in. pots........ . . . 30 $2.50 \quad 20.00$

sarmentosum Stringy StONECROP

$2 \frac{1}{2}$ in. pots .............. $30 \quad 2.50 \quad 18.00$

sieboldii Siebold Stonecrop

2 in. pots....... . . . . $35 \quad 3.00 \quad 25.00$

Sllene maritima SEA CATCHFLY

2 in. pots............. $30 \quad 2.50 \quad 18.00$

Stellaria holostea EASTERBELLS

2 in. pots.............. $35 \quad 2.50 \quad 18.00$

Thymus serpyllum Mother-of-Thyme

$2 \frac{1}{2}$ in. pots.............. $30 \quad 2.50 \quad 18.00$

coccineus CRIMSON THYME

$2 \frac{1}{2}$ in. pots........ . . . $30 \quad 2.50 \quad 18.00$

lanuginosus Woolly Thyмe

$8 \frac{1}{2}$ in. pots............ $30 \quad 2.50 \quad 18.00$

Vaccineum vitis-Idaea minor MOUNTAIN CRANBERRY

$3 \frac{1}{4}$ in. pots heavy ..... $\quad .85 \quad 6.00 \quad 50.00$

Veronica rupestris Rock SPEEdwell

$2 \frac{1}{2}$ in. pots strong ...... $\quad .30^{\circ} \quad 2.50 \quad 18.00$

var. rosea

$2 \frac{1}{2}$ in. pots....... . . . . 35 $3500 \quad 25.00$

Vinca alba 2 years White Common Periwinkle

$2 \frac{1}{2}$ in. pots ....... $40 \quad 3.50$

minor 2 years Common Periwinkle

$2 \frac{1}{2}$ in. pots ..... $\$ 120 \mathrm{M} \quad .25 \quad 2.00 \quad 15.00$

Viola cornuta alba

3 in. pots........... $35 \quad 3.00$

Jersey Gem

3 in. pots....... . . . $35 \quad 3.00$

Plant Bearberry and Scotch Heather near the sea 
Cornus paniculata Gray Dogwood

\section{Each $10 \quad 900$}

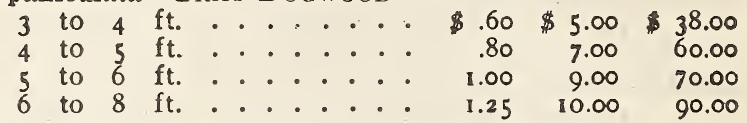

stolontfera lutea Yellow BARKED Dogwood

3 to $4 \mathrm{ft}$. . . . . . . $60 \quad 5.00$

Cotoneaster franchetl Franchet Cotoneaster

It to $2 \mathrm{ft}$. . . . . . . . $50 \quad 5.00$

2 to 3 ft. XX bushy ... $\quad .75 \quad 6.00$ rotundifolia (Wheeler's) ROUNDLEAF COTONEASTER

15 to 18 in. .......... 60 5.00

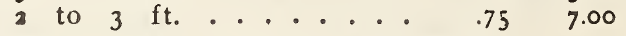

Crataegus arnoldiana ARNOLD's HAwTHORN

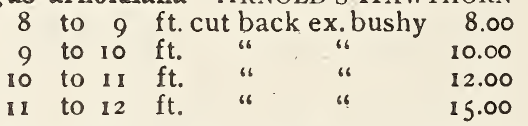

This is one of the rarest and most beautiful of all Hawthorns. It has large white flowers in early spring. Even the young trees offered by us bear quantities of large round edible scarlet fruits in August and September, and, later, the substantial leaves turn a beautiful scarlet. A beautiful small flowering tree, suitable as a specimen, for planting in groups on the edges of woods, or near the sea.

Enkianthus campanulatus Redvein Enkianthus

$$
\begin{aligned}
& 15 \text { to } 18 \text { in. bushy . . . . } 1.75 \quad 13.75 \\
& \text { It to } 2 \text { ft. bushy .... } 2.00 \quad 17.50
\end{aligned}
$$

Euonymus alatus Winged EUONYMus

$$
8 \text { to } 12 \text { ft. bushy ... } 6 \text { to } 8.00
$$

Forsythla intermedia BORDER FORSYTHIA primulina Primrose Forsythia

$$
\begin{aligned}
& 2 \text { to } 3 \mathrm{ft} \ldots \ldots . . .1 .00 \\
& 3 \text { to } 4 \mathrm{ft} \text {......... } 1.50 \\
& \text { europaea Albanian Forsythia } \\
& 3 \text { to } 4 \mathrm{ft} . \ldots \ldots . . . .25
\end{aligned}
$$

spectabllis Showy BORDER ForsythiA

2 to $3 \mathrm{ft}$. . . . . . 1.25

2 to $3 \mathrm{ft}$......... 504.00

3 to $4 \mathrm{ft}$........... $55 \quad 4.50$

fortunel Fortune Forsythia

2 to $3 \mathrm{ft} . \ldots \ldots . . .50 \quad .50$

3 to 4 ft. . . . . . . 60 5.00

virldissima Greenstem Forsythia

3 to $4 \mathrm{ft}$........ $50 \quad 4.00$

Hamamelis virginiana Common Witch HAZEL

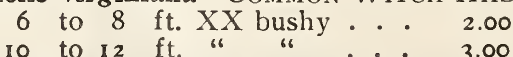

Hydrangea arborescens grandiflora SHOOTH HYDRANGEA

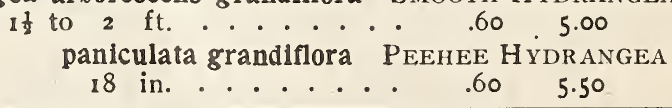

Plant Bearberry and Scotch Heather near the sea 
TREES, SHRUBS AND VINES.

Each 10

Hypericum aureum GOLdEN ST. JOHN'S WORT

$$
2 \text { to } 3 \mathrm{ft} \text {. ........ } \$ .60 \$ 5.00 \$
$$

Ilex verticillata COMMON WINTERBERRY

$$
3 \text { to } 4 \mathrm{ft} \text {. . . . . . } 1.00 \quad 8.50
$$

Ligustrum amurense AMUR River Privet

It to $2 \mathrm{ft.} \ldots \ldots . . .0 .40 \quad 3.00 \quad 25.00$

2 to $3 \mathrm{ft}$. . . . . . $\begin{array}{llll}45 & 3.50 & 30.00\end{array}$

A hardy Privet with the habit of California Prive

ibota IBOTA PRIVET

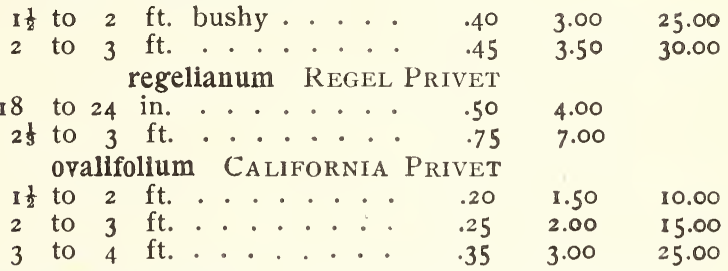

Lonicera japonica halleana HALL JAPANESE HONEYSUCKLE

$$
4 \text { yrs. XX heavy .. } .75 \quad 6.00
$$

korolkowi floribunda

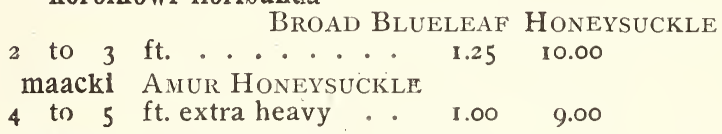

Malus arnoldiana ARNOLD CRAB

2 to $3 \mathrm{ft}$....... 4.00

coronaris Wild SweEt CRab

3 to $4 \mathrm{ft}$. . . . 4.00

floribunda JAPANESE F LOWERING CRAB

2 to $3 \mathrm{ft}$. . . . 3.00

floribunda atrosanguinea CARMINE CRAB

4 to $5 \mathrm{ft}$. . . 4.00

halliana parkmanni PARKMAN CRAB

3 to 4 ft. tr.pl. r92 I . 4.00 ioensis plena BEGHTEL CRAB

3 to $4 \mathrm{ft}$....... 3.00

sargenti SARGENT CRAB

2 to $3 \mathrm{ft}$...... 3.00

3 to $3 \frac{1}{2} \mathrm{ft} \ldots \ldots . . .500$

$3 \frac{1}{2}$ to $4 \mathrm{ft}$...... 7.50

sieboldi calocarpa TorINGo CRAB

4 ft. ..... 5.00

spectabilis Chinese Flowering Crab

4 to $5 \mathrm{ft}$. . . . 3.75

5 to $6 \mathrm{ft}$...... 5.00

spectabilis var. riversi rosea plena

Double Pink Chinese Flowering Crab

4 to $5 \mathrm{ft}$...... 6.00

toringoides CUTLEAF CRAB

2 to $3 \mathrm{ft} \ldots \ldots 3.00$ 
TREES, SHRUBS AND VINES.

Each 10

Myrica carolinensis NORTHERN BAyBERry

12 to 15 in. bushy . . . . \$.50 \$4.00\$

Phlladelphus coronarius SweEt Mock ORANGE

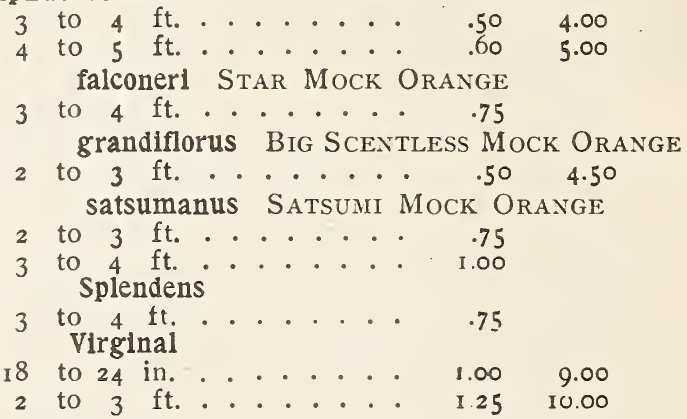

Photinia villosa Deciduous Photinia

$$
4 \mathrm{ft} . \ldots 2.50
$$

Potentilla fruticosa veitchi Veitch White Cinquefoll

$$
\begin{aligned}
& 18 \text { to } 24 \text { in. bushy . . } 1.00 \quad 7.50^{\circ} \\
& \text { parvifolia PuRdon DeEP Yellow CinQUeFoll } \\
& 15 \text { to } 18 \text { in.......... } 75 \quad 6.00 \\
& 18 \text { to } 24 \text { in.......... } 1.008 .00 \\
& 2 \text { to } 3 \mathrm{ft} \text {. . . . } 1.25 \quad 10.00 \\
& \text { var. purdoni } \\
& 18 \text { to } 24 \text { in. }
\end{aligned}
$$

The white and deep yellow Potentillas are charming shrubs of low habit. Their arching branches are covered with delicate divided leaves, and small single flowers, like tiny roses, continuing to bloom from early spring until frost. As a low shrub in the foreground of shrubbery or for the rockery these shrubs are invaluable.

Prunus serrulata sachalinensis (SARGENT) YAMA CHERrY

$$
\begin{aligned}
& 5 \text { to } 6 \mathrm{ft} \text { tr. } 1022 \ldots . .500 \quad 45.00 \\
& 7 \text { to } 8 \text { ft. spec. tr. I921 . I2.50 } \\
& 8 \text { to } 10 \mathrm{ft} \text {. spec. . . 22.50 } \\
& 12 \text { to } 15 \text { ft. spec. } 3-5 \text { in. cal. } \\
& 35 \text { to } 60 \\
& \text { Dug with platform and canvas } \\
& \text { Schnee JAPANEse Cherry Single white } \\
& 4 \text { to } 5 \text { ft. } 8 \text { ft. spec. } \therefore 750 \\
& \text { subhirtella Higan Cherry } \\
& 4 \text { to } 5 \mathrm{ft.} \ldots \ldots . . .500 \\
& 5 \text { to } 6 \text { ft. } \ldots \ldots \\
& \text { tomentosa NANking ChERry } \\
& 3 \text { to } 4 \mathrm{ft} \text {. extra heavy . I I.50 } \\
& \text { trlloba Flowering Plum } \\
& 2 \text { to } 3 \mathrm{ft} \text {........ } 1.00
\end{aligned}
$$


Rhodotypos kerrioldes JELBEAD

$\begin{array}{ccc}\text { Each } & 10 & 100 \\ \$ .50 & 4.50 & 40.00 \\ .85 & 7.00 & \end{array}$

Rhus aromatica FRAGRANT SUMACH

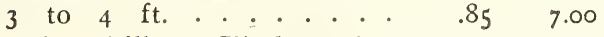

Rosa American Pillar Climber of strong growth with rich glossy foliage and huge clusters of large, cherry-colored howers

$$
\begin{aligned}
& 2 \text { yr. } \\
& 2 \text { to } 3 \mathrm{ft} \text {. XX str. ... } 1.00 \\
& 3 \text { to } 4 \mathrm{ft} \text {....... } \mathrm{I} .50
\end{aligned}
$$

Apple Blossom Dawson hybrid Single pink

3 to $4 \mathrm{ft}$......... 1.00

Blanc Double de Coubert Hybrid Rugosa with strong growth, rich foliage, and pure double white flowers

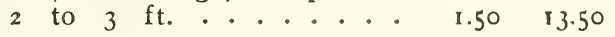

Christine Wright Climbing Pink American Beauty

$$
\text { I8 to } 24 \text { in. ......... } 1.50 \text { I3.50 }
$$

Crimson Rambler Old fashioned climbing rose with rich crimson semi double flowers in late June and early July.

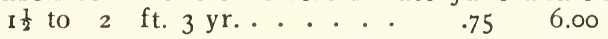

Cynthia E. Hollis Dawson hybrid Pale double pink

$$
2 \text { to } 3 \mathrm{ft} \text {....... } 2.50
$$

Dawson A Dawson hybrid climber of rambler habit. Flowers semi-double, deep pink in large clusters. Early

$$
\mathrm{I} \frac{\mathrm{s}}{2} \text { to } 2 \mathrm{ft} .3 \mathrm{yr} \text {....... } .75 \quad 6.00
$$

Daybreak A Dawson hybrid. A climber with glossy foliage and large clusters of single deep salmon pink flowers in July

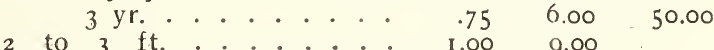

Dorothy Perkins Bright Pink Rambler

$$
3 \text { yr. strong...... . . . . } \quad .75 \quad 6.00 \quad 50.00
$$

Dr. Van Fleet Strong growing climber with glossy foliage and large double shell pink flowers in early July
3 to $4 \mathrm{ft}$.
I. 50

Excelsa Climbing wichuraiana hybrid bearing clusters of double brilliant red flowers late in season
2 yr.strong . . . . $\quad .75 \quad 6.00$
2 to $3 \mathrm{ft}$. XX strong... $1.00 \quad 9.00$
3 to $4 \mathrm{ft}$. XXX strong. . $\mathbf{I} .25 \quad \mathbf{I} 0.00$

Gruss au Tepletz Red Hybrid Tea

$$
2 \text { yr.strong . . . . } 1.00 \quad 9.00
$$

Harrison's Yellow Old-fashioned yellow Rose

$$
2 \text { to } 3 \mathrm{ft} .3 \mathrm{yr} \text {. strong .. I.25 }
$$

Hiawatha Climber, single scarlet flowers, white center
2 to $3 \mathrm{ft}$
3 to 4 ft.
$\mathrm{ft} . \cdot \cdot \cdot \cdot \cdot \cdot$
.75
6.00

Lady Duncan A Dawson hybrid, semi-climber, with rich green, rugosa-like foliage, and large clear, salmon-pink flowers, blooming in late June. Absolutely free from injurious pests $3 \mathrm{yr}$. str. plants 4.00

Lady Gay Pink climber much like Dorothy Perkins

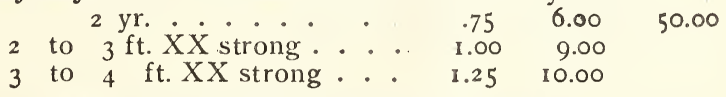


Rosa lucida Virginia Rose A wild rose bush, with single, pink flowers
2 to $2 \frac{1}{2} \mathrm{ft} . \cdots \cdots . . . \cdots \quad \$ .55 \$ 4.50 \$$
alba A white bush rose
I5 to 18 in. ........... $50 \quad 4.50$

Minnie Dawson Dawson hybrid. Rambler of the Dawson habit, the flowers small double white borne in large clusters, early in the season. The Dawson and Minnie Dawson are the earliest to bloom of all climbers, flowering in our vicinity sometimes in late May, always in early June

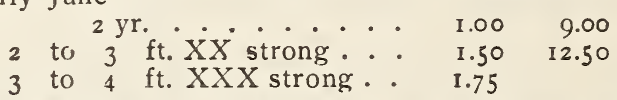

Mme. Plantier Old-fashioned, double-flowered white rose

$$
2 \text { to } 3 \mathrm{ft} \text {............. } 1.00
$$

multiflora Japanese white climbing rose

$$
3 \text { to } 4 \mathrm{ft} \text {........ } 40 \quad 4.00
$$

var. catheyensis Cathay rose, a climbing rose with single pink flowers

$$
2 \text { to } 3 \text { ft. bushy . . . . I I.00 } 9.00
$$

omlensis Mount Omei Rose A bush rose

$$
18 \text { to } 24 \text { in. bushy .... } 1.00 \quad 9.00
$$

Paradise A climbing rose with single pink flowers

$$
3 \mathrm{ft} \text {. . . . . . } 1.25 \quad 10.00
$$

Paul's Scarlet Climber New climbing rose with large double clear scarlet flowers

$$
3 \text { to } 4 \text { ft. } 3 \text { yr..... I. } 50
$$

Pauline Dawson A Dawson hybrid climber or pillar rose of good foliage and large single deep pink flowers

$$
\begin{array}{llll}
2 & \text { to } 3 & \mathrm{ft} . \mathrm{XX} \text { strong... } & \mathrm{I} .50 \\
3 & \text { to } 4 & \mathrm{ft} . \mathrm{spec} . . . . . . & 2 . \mathrm{Co}
\end{array}
$$

Persian Yellow Double deep yellow flowers
2 to $3 \mathrm{ft}$. strong.
I.25 10.00

Purity A large-flowered white climber, similar to Silver Moon, but hardier and flowers more freely

$$
2 \text { to } 3 \mathrm{ft} .3 \text { yrs. .... } 1.50
$$

rugosa repens alba Climbing or creeping white-flowered rugosa hybrid, with glossy foliage and large star-shaped white flowers

$$
2 \mathrm{ft} \text {. spread.... } \mathbf{2 . 0 0}
$$

Seashell Dawson hybrid Climber which has glossy foliage and large clusters of large, semi-double pink flowers, blooming in July

$$
\begin{array}{llll}
I \frac{1}{2} & \text { to } 2 \mathrm{ft} \text {. spread.... } & \text { I.25 } & \text { II.50 }
\end{array}
$$

setigera PRAIRIE ROSE, pink

$$
18 \text { to } 24 \text { in. ....... . . . . . } 45 \quad 3.75
$$

Silver Moon A climber, which has single, cream white flowers

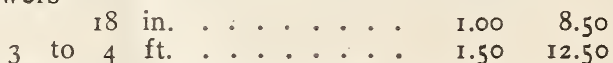

wichuralana Wichurian Rose Single white, climbing or creeping with glossy foliage

$$
2 \text { to } 3 \mathrm{ft} . \cdots . . . .75
$$




\section{Each 10}

William C. Egan A Dawson hybrid, climber, with good foliage and large very double pink flowers. Late June. The Egan Rose is one of the very satisfactory climbing Roses. Its foliage is pleasing, and is never attacked by insects, it does not die back in hard winters, and even when very small it is covered with the large, very double fragrant roses

$$
\begin{aligned}
& 2 \text { to } 3 \mathrm{ft} . \ldots \ldots \ldots \text {..... } \$ 1.50 \$ 12.50 \text { \$ } \\
& 3 \text { to } 4 \mathrm{ft} \text {...... } 2.00 \text { I } 5.00
\end{aligned}
$$

All the Roses listed above are thrifty two to three-year old plants which were planted from pots last spring, and will lift with good roots

Hybrid Perpetual and Hybrid Tea Roses We have a limited supply of Hybrid Roses including Paul Neyron, Genenal Jacqueminot, Los Angeles, Pink Druski, Frau Karl Druski, Magna Charta, and Mme. Edward Herriott

$$
\text { I } \frac{1}{2} \mathrm{ft} \text {. bushy .... } 1.00
$$

Spiraea ovallfolia (callosa alba) WhITE JAPANESE SPIREA

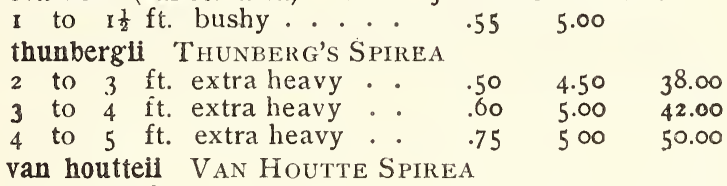

2 to $3 \mathrm{ft}$........... $40 \quad 3.50 \quad 30.00$

Symphoricarpus (conglomerata) chenaulti

ro to 12 in. ....... 1.00

racemosus COMMON SNOWBERRY

18 to 24 in. . . . . . . . $50 \quad 4.00 \quad 36.00$

Symplocos paniculata (crataegoldes) Asiatic SweEtLeaf

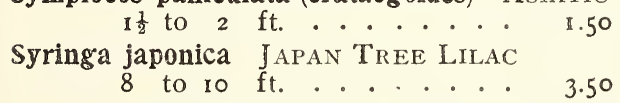

vulgaris var. alba Common White Lilac

2 to $3 \mathrm{ft}$........ $60 \quad 5.50$

var. Charles $\mathbf{X}$ single dark reddish purple

3 to $4 \mathrm{ft}$...... 2.25

var. Ludwig Spath Deep reddish purple

2 to $3 \mathrm{ft}$...... 1.50

var. Marie Legraye Single white

2 to $3 \mathrm{ft}$....... $1.50 \quad 12.50$

2 to $3 \mathrm{ft}$. heavy....

var. Mme. Lemoine Double white, very fine

2 to 2 ft. ......... $1.50 \quad 13.50$

var. Volcan Large, single dark reddish purple

4 to $5 \mathrm{ft}$..... 3.75

var. William Robinson Double Pink

2 to $3 \mathrm{ft}$. heavy.... $1.65 \quad 15.00$ 
Ulmus americana AMERICAN ELM

I5 to 18 ft. 3 to 4 in. cal. . .

$7 \cdot 50$ to 10.00

glabra Scotch ELM

Io to $12 \mathrm{ft}$. . . . 7.50 to 10.00

Viburnum canbyi CANBY VIBURNUM

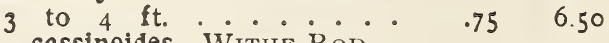

cassinoides WiTHE ROD

2 to $3 \mathrm{ft}$. ........... 650

3 to $5 \mathrm{ft}$. coll. spec. clps. - 1.50

dentatum ARROWWOOD

2 to $3 \mathrm{ft}$......... $60 \quad 5.00$

3 to $4 \mathrm{ft} . \ldots . . . . .750$

dilatatum LINDEN VIBURNUM

2 to 2 t $\mathrm{ft}$........... $1.75 \quad 15.00$

opulus European Cranberry Bush

2 to $3 \mathrm{ft}$........... 65 6.00 pubescens Downy VIBURNum

2 to $2 \frac{1}{2} \mathrm{ft}$. . . . . $1.00 \quad 9.00$

Zenobia pulverulenta (Andromeda speciosa) Dusty Zenobia I t to $2 \mathrm{ft}$........ 3.00 


\section{HARDY HERBACEOUS PERENNIALS}

Except where noted 30 cents each, \$2.40 per ten $\$ 18.00$ per hundred

25 perennials of one kind are priced at the hundred rate when a hundred rate is listed

\begin{tabular}{ccccc} 
& \multicolumn{3}{c}{ Each 10} & 100 \\
Achillea ptarmica “The PEARL" SNEEZEWORT & $\$ .25$ & $\$ 2.20 \$ 15.00$
\end{tabular}

Aconltum acutum EARLy ACONITE . $\quad .40 \quad 3.50 \quad 25.00$

AJuga generensis CReeping BUGLE

Agrostemma coronaria ROSE CAMPION

Alyssum saratile compactum GoLD-DUST

Anthericum llilago ST. BERNARD's LILY

Aquilegia callfornica HyBRIDS ... $\begin{array}{llll}.25 & 2.20 & 15.00\end{array}$

canadensis American Columbine

$.25 \quad 2.20 \quad 15.00$

chrysantha Golden Columbine

coerulea Colorado Columbine

delicatissimum Long-spurred hybrids

nivea grandiflora Munstead White Columbine

Rose Queen Pink, long-spurred hybrids

$$
\begin{array}{lll}
.25 & 2.20 & \text { I } 5.00
\end{array}
$$

$.25 \quad 2.20 \quad 15.00$

Arenaria caespitosa Moss SANDWORT

Ascleplos tuberosa BUTterfLy WEED $.35 \quad 3.00$

Aster alplna ROCK AsTER

Climax Tall Blue Aster

ericoldes White HeAth Aster

Novac Angliae rubra Rosy NEw ENGLAND Aster

Tall, rose pink

St. Egwyn Bright pink

Astible japonica JAPAnese Astible

Baptisia australls WILD-INDIGO $\ldots \begin{array}{llll}.25 & 8.20 & 15.00\end{array}$

Boltonia asteroldes White Boltonia $\quad .25 \quad 2.20 \quad 15.00$

$\begin{array}{llll}\text { latisquama VIOLET BOLTONIA } & .25 & 2.20 & \mathbf{5} .00\end{array}$

Buddleia magnifica OXEYE BUTTERfLy

2 yrs. $. . . \cdot . \cdot 50 \quad 4.00$

Callirhoe involucrata Low Poppy-Mallow

.50

Campanula carpatica Carpathian Bellflower

persieaefolla PEACHLEAF BELLFLOWER alba Petticoat Bellflower

$\begin{array}{lllll}\text { Centaurea montana } & \text { Mountain Bluet } & .25 & 2.20 & \mathbf{1 5} .00\end{array}$

Cerastium bleberstelmI TAURUS CERASTIUM

$\begin{array}{lllll}\text { Coreopsis grándiflora } & \text { BIG COREOPSIS } & .25 & 2.20 & 15.00\end{array}$

Daphne cneorum ROSE DAPHNE

2 yr. clumps … $1.00 \quad 8.50$ 
Delphineum chinense SLENDER LARKSPUeh $10 \quad 100$ var. Blue Butterfly New

hybridum MOUNTAIN LARKSPUR

$$
\text { Bella Donna Light blue }
$$

Delphineum hybridum bellamosum

dark blue form of Belladonna mixed

Dianthus barbatus SWEET WiLLIAM red, white, pink beauty

$$
\begin{array}{lllll}
\text { plumarius Grass PINK } & .25 & 2.20 & 15.00
\end{array}
$$

$\begin{array}{llrlr}\text { Dicentra spectabills BleEdingHeART } & 1.00 & 9.00 & \\ \text { Digitalis ambigua Foxglove Yellow } & .25 & 2.20 & 1500\end{array}$

Digitalis ambigua Foxglove Yellow .25
alba FoxGLOVE White

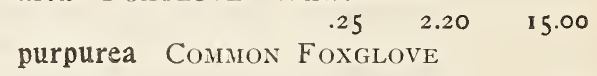

Echinops rito Steel Globethistle

$.25 \quad 2.20 \quad 15.00$

Eryngium amethystinum Anethyst ERINGO

Festuca glaúca Fescoe Grass Blue

Galllardia aristata (gr. fl.) Common Perennial Gaillardia

Gillenla stipulata INDIAN-PHYSIC

$\begin{array}{lll}.25 & 2.20 \quad 15.00\end{array}$

Gypsophila paniculata BABY'S BREATH

repens CREEPING BABY'S BREATH

Helianthus mollis var. cordatus $\begin{array}{lllll}. . & .25 & 2.20 & 1500\end{array}$

Hemerocallis Apricot DaYLILY Yellow

dumortieri DAYLILY Early

flava DAYLILY Lemon

fulva DAYLILY Tawny

thunbergil JAPANESE DAYLILY

Hibiscus hybridus RoSEMALLOw giant pink and white

$.50 \quad 4.50$

Hosta (Funkia) lancifolia Lanceleaf Plantainlily

Hypericum buckleyl. Mountain St. Johnswort

Iberis sempervirens Evergreen CANDytufT

$$
.75 \quad 650
$$

\section{var. LitTle GEM}

Dwarf Evergreen Candytuft

Inula ensifolia SWORDLEAF INULA

Iris Celeste Blue

Florentina Florentine IrIS. White

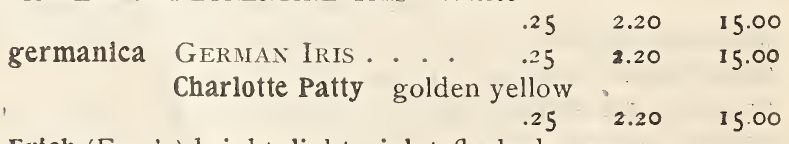

Erich (Farr's) bright, light violet flushed rose

$$
.75 \quad 7.00
$$

Fairy Queen white, falls veined in blue

$\begin{array}{lll}.25 & 2.20 \quad 15.00\end{array}$

Plant Bearberry and Scotch Heather near the sea 


\section{Each $10 \quad 100$}

Iris Frich (Farr's) Garrick standards light blue falls a dark blue $\$ .25 \$ 2.20 \$ 15.00$ Mme. Chereau white, edges of petals blue
Quaker Lady (Farr's)
s. smoky lavender with yellow shadings
f. ageratum blue and old gold
Rhein nixe (G \& $\mathrm{K}$ 1910)

$$
\begin{array}{ll}
.50 \quad 4.50 \\
.
\end{array}
$$
s. pure white
f, deep violet blue with white edge
$\begin{array}{lllll} & .50 & 4.20 & \\ \text { kaempferi laevigata JAPANESE IRIS } & .35 & 2.50 & \\ \text { pallida Dalmatica. . . . . . . . } & .35 & 3.00 & 24.00\end{array}$
Speciosa ......
pumila dwarf, deep purple
pseudacorus YELLOW FLAG
siberica SibERIAN IRIS
alba SIBERIAN IRIS White

\begin{tabular}{llll} 
& .25 & 2.20 & 15.00 \\
orientalis ORIENTAL IRIS & .25 & 2.20 & 15.00 \\
Snow Queen ORIENTAL IRIS & White \\
\cline { 2 - 4 } & .25 & 2.20 & 15.00
\end{tabular}

$\begin{array}{lll}.25 & 2.20 & 15.00\end{array}$

Liatris splcata SPIKE GAYFEATHER

Linum perenne Perennial Flax

Lipachys pinnata Yellow CONE Flower

Lupinus polyphyllus WASHINGTON LUPINE White, blue,pink Lysimachia nummularia MONEYwORT

vulgaris Golden LOOSESTRIFE

Lythrum salicaria PURPLE LoOSESTRIFE

Nepeta Mussini

Oenothera fruticosa youngi Youngs SUndrops

Paeonias mixed large clumps ... . . $60 \quad 5.50$

Phlox amoena Dwarf Phlox ... $\quad .25 \quad 2.20 \quad 15.00$ paniculata Albion white with pink eye

$\begin{array}{lll}.25 & 2.20 \quad 15.00\end{array}$

Antoine Mercie pale lilac, white star in center

Aurora Borealis Salmon scarlet, deep crimson eye B. Comte Rich, dark crimson red, late blooming Bridesmaid White with large rosy center

Cyclone white, dark carmine eye

Czarina fine white, tall and late

Eclaireur deep carmine, rosy salmon center

Ettas Chorse pure white

F. G. Van Lastburg large flowers. white

Hermione dwarf white, large flowers

H. 0. Wijers white, with large red eye. Low Independence white, medium, early

Jean d'Arc tall, late, white

Mme. Pape Carpentier white, large flowers, low

For prices see pages $11-12$ 


\section{Each $10 \quad 100$}

Mrs. Cook tall, soft magenta pink, very late Richard Wallace white, deep crimson eye Saison Lierval white, with light pink eye Widor bright reddish violet, large white center William Muhle Bright pink, tall, late

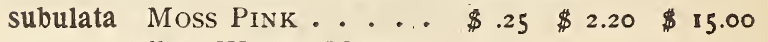

Physostegia virginica FALSE Dragonhead

Platycodon grandiflora BALLOONFLOWER

Polemonium reptans Creeping Polemonium

Rudbeckia purpurea HEDGEHOG-CONEFLOWER

Salvia azurea grandiflora Great AzURE SAgE

Sedum acre Goldmoss

lydium roseum Lydian STONECROPE

sarmentosum "Stringy "

sexangulare Hexagon

spectabilis Showy

$\begin{array}{llllll}\text { stoloniferum Running } \quad \text { “ } & .25 & 2.20 & 15.00\end{array}$

Sempervivum globiferum GLOBE Houser.eEK

\begin{tabular}{|c|c|c|c|c|}
\hline \multirow[b]{3}{*}{ tectorum } & & .25 & \multirow[t]{2}{*}{2.20} & \multirow[t]{2}{*}{15.00} \\
\hline & large clumps & .50 & & \\
\hline & \multicolumn{4}{|c|}{ ROOF HOUSELEEK } \\
\hline & large clumps & $\begin{array}{r}.25 \\
.50\end{array}$ & 2.20 & 15.00 \\
\hline
\end{tabular}

Silene maritima SEA CATCHFLY

statice latifolia BIgleaf SEA LAvender.

Stellaria holostea EASTERBELLS

Thymus serpyllum MOTHer of ThyME

coccineum CRIMSON THYME

lanuginosus Woolly Thyme

Tradescantia virginiana VIRGINIA SPIDERWORT

Tunica saxifraga SAxifrage TUNICFLOWER

Vernonia noveboracensis COMMON IRONWEED

Veronica alpestris See V. serpilifolia

gentianoldes Gentian SPEedwell

rupestris Rock SPEEDWELL

var. pink

spicata SPIKe SPEEDWELl

var. Maxima TAll Speedweld

Plant Bearberry and Scotch Heather near the sea 


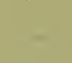

(2)
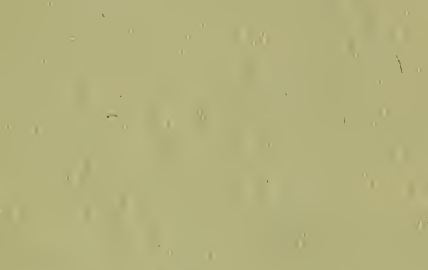


\section{HOW TO REACH OUR NURSERIES}

By train: Take train from South Station, Boston, or from Worcester and other points west, to Framingham. From Framingham, take train or electric car to Holliston. Upon being notified we will be glad to meet at Holliston any persons desiring to visit the Nurseries. Telephone Natick 345 .

By motor: From Boston the best route is via Newton, Wellesley, South Natick; from South Natick take Elliot Street, to Main Street, Sherborn, thence Main Street, Goulding Street, Mill Street, Fiske Street to the Nurseries.

From Worcester take main route to Framingham, from Framingham follow the street car track to Holliston Centre, turn sharp to left up Central Street, thence Fiske Street to the Nurseries. 